\title{
Effect of Morinda citrifolia Fruit Extract Capsule on Total Cholesterol Levels in Patients with Hypercholesterolemia
}

\author{
Grace Santhy Sasnan ${ }^{1 *}$, Endang Hanani ${ }^{1}$ and Jusuf Kristianto ${ }^{2}$ \\ ${ }^{1}$ Faculty of Pharmacy, ${ }^{2}$ Faculty of Public Health, University of Indonesia, Depok, 16424, Indonesia \\ ${ }^{*}$ For correspondence: Email: gracesanthysasnan@gmail.com; Tel: +6221-98769399; Fax: +6221-63870030
}

Received: 11 October 2013

Revised accepted: 23 June 2014

\begin{abstract}
Purpose: To investigate the reducing effect of Morinda citrifolia capsules (MCC) on total cholesterol (TC) and low-density lipoprotein cholesterol (LDL-C) in hypercholesterolemia patients.

Methods: This study was a randomized double-blind placebo-controlled clinical trial, with 60 subjects placed in two groups, viz, experimental (MCC group) and placebo ( $P$ group). The first group received two capsules of MCC (each capsule contains $500 \mathrm{mg}$ extract) while the second group received two capsules of placebo (comprised of $500 \mathrm{mg}$ fillers) 3 times daily, for 14 days for both groups. Overnight fasting cubiti venous blood $(3 \mathrm{~mL}$ ) was taken from each subject each time measurements were carried out. TC and LDL-C were measured by spectrophotometric assay using an automated analyzer.

Results: The results show that there was significant decrease in TC and LDL-C on day 14, compared to control (P group). Reduction in TC and LDL-C was 13.8 and $15.5 \%$, respectively. Decrease in TC and $L D L-C$ levels was influenced by factors, such as age, BMI, exercise, diet, and smoking habits. In MCC group, the capsules significantly decreased TC levels $(p<0.05)$.

Conclusion: The results suggest that $1 \mathrm{~g}$ MCC, given orally thrice daily, significantly reduces TC and $L D L-C$ levels in patients with hypercholesterolemia.
\end{abstract}

Keywords: Hypercholesterolemia, Cholesterol levels, Morinda citrifolia

Tropical Journal of Pharmaceutical Research is indexed by Science Citation Index (SciSearch), Scopus, International Pharmaceutical Abstract, Chemical Abstracts, Embase, Index Copernicus, EBSCO, African Index Medicus, JournalSeek, Journal Citation Reports/Science Edition, Directory of Open Access Journals (DOAJ), African Journal Online, Bioline International, Open-J-Gate and Pharmacy Abstracts

\section{INTRODUCTION}

Hypercholesterolemia is characterized by increase in serum cholesterol level above the normal values $(>200 \mathrm{mg} / \mathrm{dL})$. It is often associated with the elevated of serum lowdensity lipoprotein cholesterol (LDL-C) concentration because it carried $65-75 \%$ of total cholesterol (TC) [1,2]. The incidence of hypercholesterolemia will continue to grow unanimously as the unhealthy lifestyle such as smoking, obesity, lack of exercise and the consumption of high-fat meals. The increase of TC and LDL-C can be modified by nonpharmacology therapy, such as changes in life style and habits (e.g., inclulging in exercise, diet and no smoking) and pharmacotherapy (medication use) [3]; thus, the process of atherosclerosis can be prevented as early as possible [4-7].

Morinda citrifolia (MC) is commonly known as "Noni" [8,9]. MC fruit has been used as a traditional medicine for about 2000 years. It has many effects and activities, such as antibacterial, antiviral, anti-diabetes, antihypertensive, immunostimulatory, and anticancer [10]. MC fruit contains polysaccharides, fatty acid, glycosides, iridoids, anthraquinones, coumarins, flavonoids, lignans, phytosterols, and carotenoids [9]. MC 
has a wide safety range, its $L D_{50}$ more than $15.000 \mathrm{mg} / \mathrm{kg}[11,12]$ and can be tolerated up to $10 \mathrm{~g} /$ day with no side effects [13]. MC is one of many plants with fruit that could decrease the TC and LDL-C and has been studied in mice [14]. Series of clinical studies in America proved that MC fruit juice could decrease the TC and LDL-C significantly in hypercholesterolemia patients with smoking habits [15-17]. The clinical usage of MC fruit in hypercholesterolemia patients as reported warrants further evaluation in more subjects. In this study, we evaluated the effect of oral administration of MCC in 60 subjects with hypercholesterolemia.

\section{EXPERIMENTAL}

\section{Materials}

Each $500 \mathrm{mg}$ Morinda citrifolia capsule (MCC) containing $90 \%$ dry extract of $\mathrm{MC}$ fruits and 10 $\%$ filler and was registered for sale in Indonesia.

\section{Design}

This study was conducted between April and October 2012, and was a double-blind design, randomized controlled clinical trial, conducted in patients at a clinic in South Jakarta, Indonesia.

\section{METHODS}

Subjects were randomly assigned into two groups: MCC group and the $\mathrm{P}$ group. Each subjects received a material study and they were monitored every Monday and Thursday to evaluate the outcome for 14 days. The age, sex, body mass index, and compliance of all the subjects with the standard diet regimen (low fat diet), exercise, and smoking behavior was assessed using a questionnaire, based on crosssectional study, at the end of study. Blood samples were collected twice a week to determine the TC and LDL-C values in the laboratory during the study. The values of TC and LDL-C were determined from fasting blood cholesterol. They were measured at baseline, day $3,7,10$ and 14 of study period. Overnight fasting venous blood ( $3 \mathrm{~mL}$ ) was taken from each subject each time the measurements were done. The TC and LDL-C were measured using enzymatic methods by spectrophotometric assays on automated chemistry analyzer. The blood was taken at the laboratory of Biomedika, South Jakarta, Indonesia and analyzed using a reagent kit (Roche Diagnostics, $\mathrm{GmBH}$, Manheim, Germany)

\section{Subjects}

The Ethics Committee of the Faculty of Medicine, University of Indonesia - Cipto Mangunkusumo Hospital, Central Jakarta, Indonesia reviewed the research protocol used and approved it (Reg. no. 127/PT02.FK/ETIK/2012); followed the guidelines of World Medical Association Declaration of Helsinki, Ethical Principles for Medical Research Involving Human Subjects [18]. The 60 subjects were selected for the study using the following criteria. The inclusion criteria for this study are diagnosis of hypercholesterolemia with an increased TC > $200 \mathrm{mg} / \mathrm{dL}$ and LDL-C > $130 \mathrm{mg} / \mathrm{dL}$, in males and females, aged over 30 years and willing to give informed consent. Exclusion criteria were the use of supplement or drugs that will interfere with cholesterol metabolism, pregnant and breast feeding women, women with hormone replacement therapy, and patients with chronic disease. Reasons for dropping out of the study include non-compliance to protocol agreed upon at the beginning of the study, change in the type of drug that has been established at the beginning of the study, patient experiencing side effects of MCC and refusal to continue the research.

\section{Statistical analysis}

The data was analyzed by descriptive and analytical method using Students' t- and Chi square tests. Significance level was set at $p<$ 0.05 and all data were analyzed using a statistical software package (SPSS, version 17.0).

\section{RESULTS}

\section{Characteristics of subjects}

The results showed that patients who had serum total cholesterol > $200 \mathrm{mg} / \mathrm{dL}$ and LDL cholesterol > $130 \mathrm{mg} / \mathrm{dL}$ were mainly those whose age were < 40 years old (53.3\%). Overweight patients $\left(\mathrm{BMI}>25 \mathrm{~kg} / \mathrm{m}^{2}\right)$ were 55 $\%$. Also, $28.3 \%$ of patients do not engage in regular exercise. Patients on low fat diet constituted $60 \%$ while others were not. Most of the patients were non-smokers $(73.3 \%)$.

\section{Effect of MCC in hypercholesterolemic patients}

This study also showed a significant reduction of total and LDL cholesterol in experimental group compared to control group (Figures 1 and 2). 
Table 1: Demographic profile of subjects

\begin{tabular}{lccc}
\hline Variable & $\mathbf{N}(\%)$ & Control (\%) & Total (\%) \\
\hline Age & $19(63.3)$ & $13(43.3)$ & $32(53.3)$ \\
$\leq 40$ years & $11(36.7)$ & $17(56.7)$ & $28(46.7)$ \\
$>\quad 40$ years & & & \\
Sex & $16(53.3)$ & $18(60.0)$ & $34(56.7)$ \\
Male & $14(46.7)$ & $12(40.0)$ & $26(43.3)$ \\
Female & $11(36.7)$ & $16(53.3)$ & $27(45.0)$ \\
Body Mass Index & $19(63.3)$ & $14(46.7)$ & $33(55.0)$ \\
$\geq 25 \mathrm{~kg} / \mathrm{m}^{2}$ & $7(23.3)$ & $10(33.3)$ & $17(28.3)$ \\
$<25 \mathrm{~kg} / \mathrm{m}^{2}$ & $23(76.7)$ & $20(66.7)$ & $43(71.7)$ \\
Exercise & $8(26.7)$ & $16(53.3)$ & $24(40.0)$ \\
Not regular & $22(73.3)$ & $14(46.7)$ & $36(60.0)$ \\
Regular & $7(23.3)$ & $9(30.0)$ & $16(26.7)$ \\
Diet & $23(76.7)$ & $21(70.0)$ & $44(73.3)$ \\
Not compliant & & & \\
Compliant & Smoking habit & &
\end{tabular}

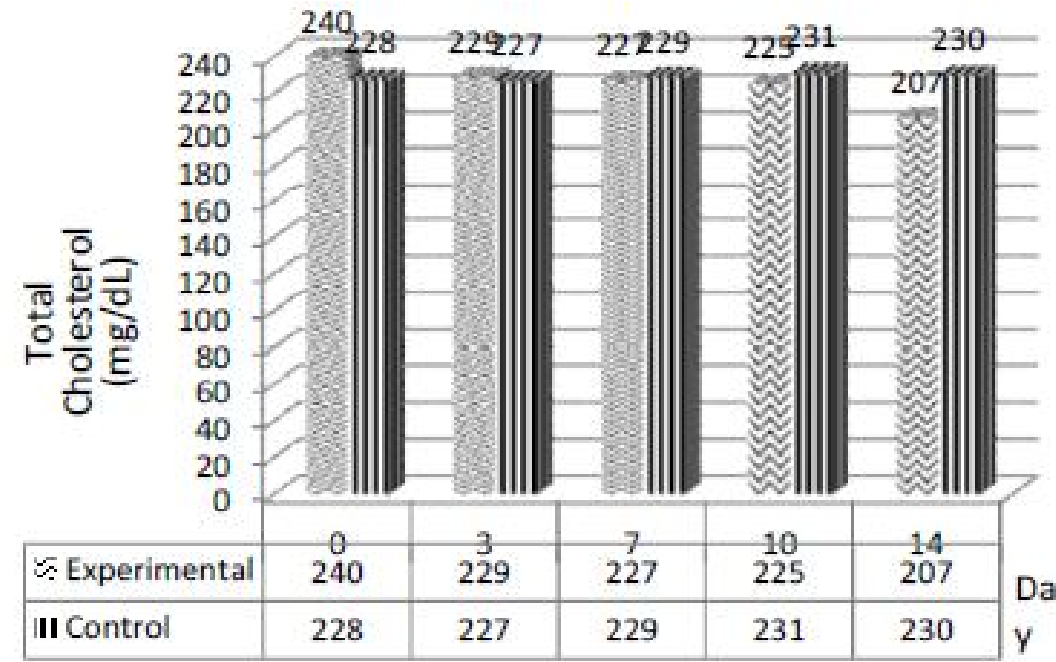

Fig 1: Effect of extract on TC levels in subjects

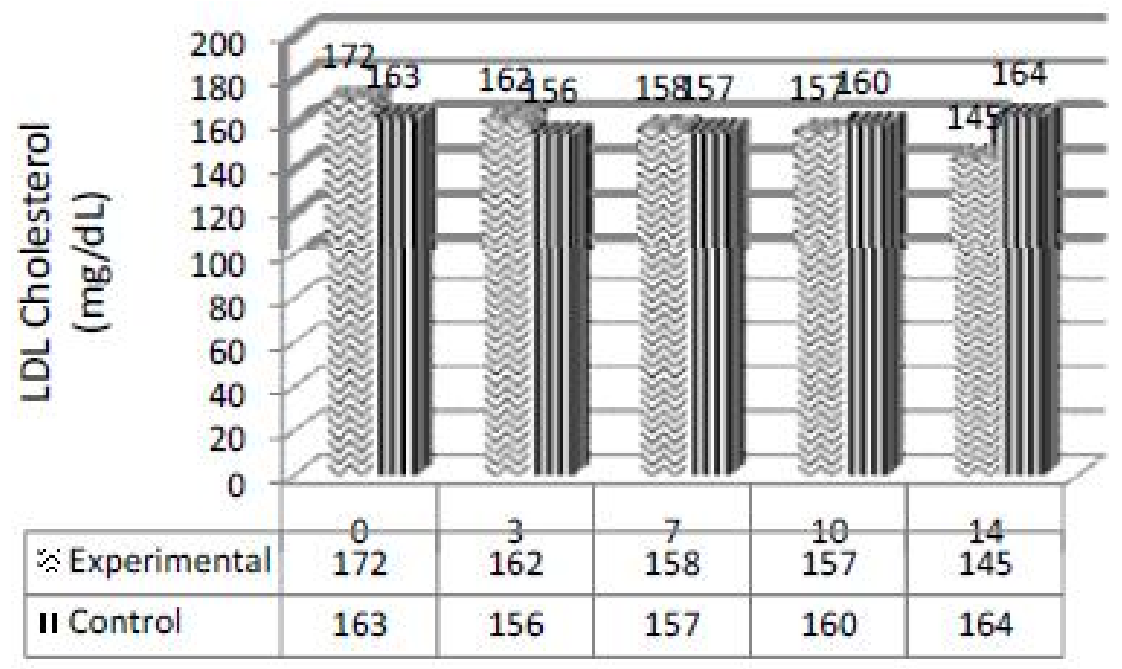

Fig 2: Effect of extract on LDL-C levels in subjects 


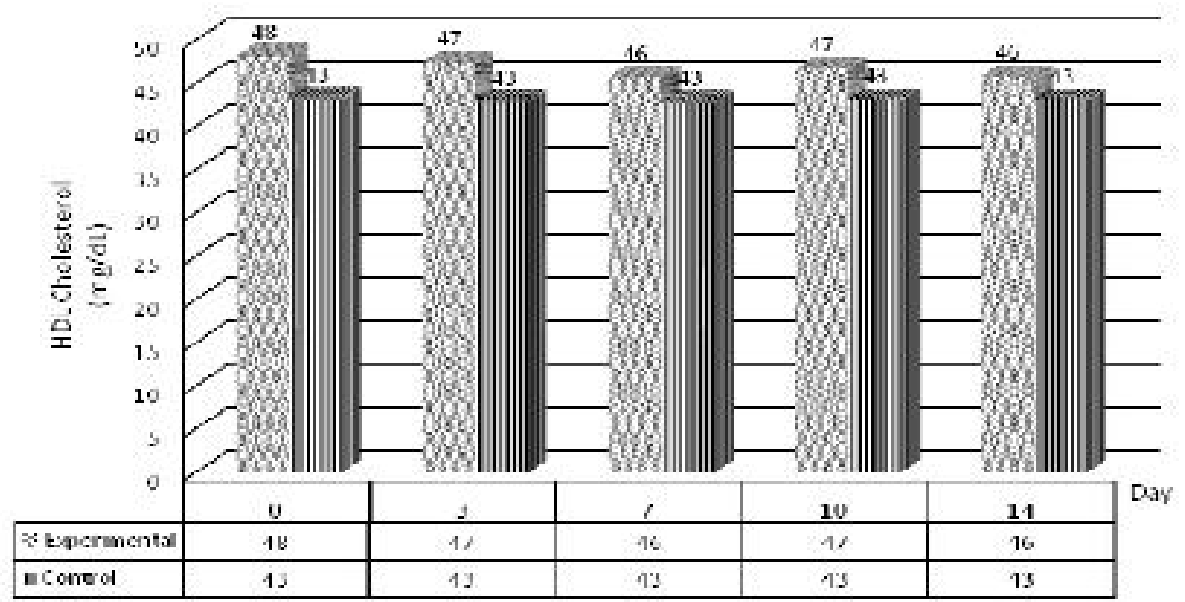

Fig 3: Effect of extract on HDL-C levels in subjects

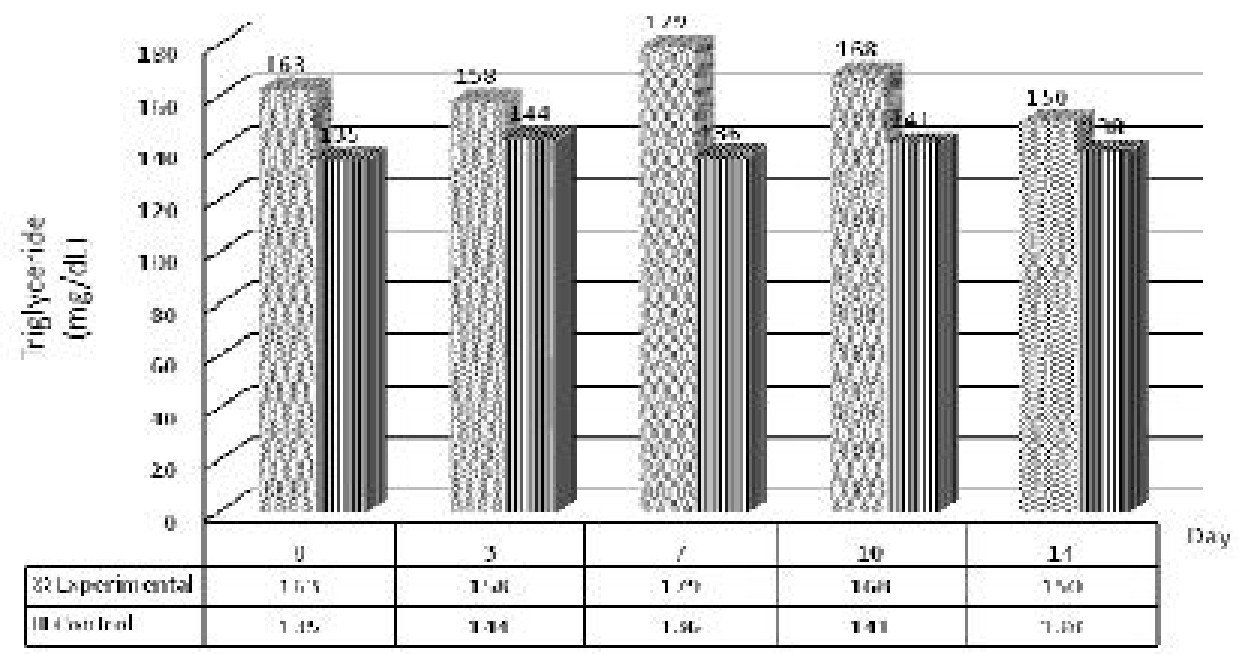

Fig 4: Effect of extract on triglyceride levels in subjects

Table 2: Profile of lipids level $(\mathrm{mg} / \mathrm{dL}$, mean $\pm \mathrm{SD})$ before and after the intervention

\begin{tabular}{lllll}
\hline Parameter & Control & \multicolumn{3}{c}{ Experimental } \\
\cline { 2 - 5 } & Day 0 & Day 14 & Day 0 & Day 14 \\
\hline Total Cholesterol & $228.2 \pm 18.7$ & $230.2 \pm 19.8$ & $240.0 \pm 26.8$ & $207.0 \pm 24.7$ \\
LDL Cholesterol & $163.0 \pm 17.5$ & $164.0 \pm 18.6$ & $171.5 \pm 22.2$ & $144.9 \pm 21.9$ \\
HDL Cholesterol & $43.1 \pm 10.7$ & $42.9 \pm 9.5$ & $48.1 \pm 12.2$ & $45.7 \pm 11.9$ \\
Triglyceride (TG) & $135.5 \pm 48.5$ & $138.4 \pm 48.5$ & $162.6 \pm 86.6$ & $150.0 \pm 73.8$ \\
\hline
\end{tabular}

As Table 2 shows, there were differences in TC and LDL-C levels in the two groups $(p<0.05)$. There was no significant difference in TC and LDL-C levels from baseline level to day 14 in the control group but there was a significant decrease in TC and LDL-C levels in the experimental group at day 14 . The reductions in TC and LDL-C were $13.8 \%(33.0 \mathrm{mg} / \mathrm{dL})$ and $15.5 \%(26.6 \mathrm{mg} / \mathrm{dL})$, respectively, using control group as the baseline. But, MCC could not increase HDL-C or decrease TG because the result showed that there are no significant differences $(p>0.05)$.

\section{Bivariate analysis}

The correlation between TC and factors that could influence the concentration of TC, such as age, sex, BMI, exercise, diet and smoking habits at the experimental group were analyzed but that between LDL-C level and the factors was not because LDL-C is the major component of TC [1]. When TC increases, the LDL-C will automatically increase too. Therefore, it would be more accurate to analyze correlation between TC and all of factors. 
Table 3 shows the results of correlation analysis between average TC reduction and factors that influence the concentration of TC in experimental group. Age was found to be associated with TC level reduction $(\mathrm{OR}=2.8 ; p=0.042)$. The TC reduction was also influenced by changes in $\mathrm{BMI}$ $(\mathrm{OR}=6.2 ; p=0.0001)$, exercise $(\mathrm{OR}=14 ; p=$ $0.001)$, diet $(\mathrm{OR}=16.3 ; p=0.0001)$ and smoking habits $(O R=14 ; p=0.001)$. The highest odd ratio (OR) was showed by dietary factor (16.3). The result shows that there were significant differences in average TC level reduction in relation to differences in age, BMI, exercise, diet and smoking habits $(p<0.05)$ while for the sex factor, there was no significant different in TC reduction $(p>0.05)$.

\section{DISCUSSION}

Morinda citrifolia (MC) is one of the traditional medicines used to treat cardiovascular diseases such as hyperlipidemia. As MC is reported to be rich in flavonoids, a polyphenol substance, which could inhibit lipid biosynthesis [19] especially by inhibiting the HMG Co-A reductase [20]. Various studies, both in humans and animals, have shown similar results in reducing effect to TC and LDL-C. Mandukhail [14] conducted a research in rats that injected high dose of lipids and the results showed that MC extract inhibited biosynthesis, absorption and secretion of lipids on day 10. Besides that, Subramanian and Rao [21] gave a result that $\mathrm{MC}$ might act as an antidiabetic, anti-hyperlipidemia and anti-oxidant in diabetic rats. In humans, Wang et al [15] found that 68 smoking volunteers who were given MC two times a day for 30 days showed reduced levels of TC and LDL-C. All the studies mentioned above produced similar results with this study. In this study, MCC reduced serum TC and LDL-C level because there were significant decreases in TC and LDL-C level $(p<0.05)$.

There are other factors that could influence TC level in human. They are age, sex, BMI, exercise, diet and smoking habits. The first factor was age $(\mathrm{OR}=2.8 ; p=0.042)$. Serum TC level starts to increase at 20 years old and continues until 60-65 years old [5]. Devroey et al [22] observed that increase in TC and LDL-C levels correlates with increase in age. However, in other studies by Raitakari et al [23], dyslipidemia was found in children and adolescents. Indonesian Health Household Survey in 2004 [24] stated that hypercholesterolemic patients had been shifted from the usual age. They showed that hypercholesterolemic patients whose ages range between 25 - 34 years old was $9.3 \%$. In this study, subjects under 40 years old showed greater reduction lipid levels following consumption of MC fruit extract capsule.

From this study, sex did not give a significant decrease in TC level. Theoretically, before the age of 50 , TC in males might be higher than in females at the same age. But, after the age of 50 the reverse is the case. It is caused by hormonal effect in females after menopause. After menopause (natural or surgical) TC would rise so

Table 3: Correlation analysis results between average TC reduction and factors that influence TC reduction in experimental group $(n=30)$

\begin{tabular}{|c|c|c|c|c|}
\hline \multirow[t]{2}{*}{ Variable } & \multicolumn{2}{|c|}{ Reduction } & \multirow[t]{2}{*}{ OR } & \multirow[t]{2}{*}{$p^{*}$} \\
\hline & Mild & Good & & \\
\hline \multicolumn{5}{|l|}{ Age } \\
\hline$\leq 40$ years & $3(33.3 \%)$ & $16(76.2 \%)$ & 2.8 & 0.042 \\
\hline$>40$ years & $6(66.7 \%)$ & $5(23.8 \%)$ & & \\
\hline \multicolumn{5}{|l|}{ Sex } \\
\hline Male & $6(66.7 \%)$ & $10(47.6 \%)$ & - & 0.440 \\
\hline Female & $3(33.3 \%)$ & $11(52.4 \%)$ & & \\
\hline \multicolumn{5}{|l|}{ Body mass index } \\
\hline$\geq 25 \mathrm{~kg} / \mathrm{m}^{2}$ & $8(88.9 \%)$ & $3(14.3 \%)$ & 6.2 & 0.0001 \\
\hline$<25 \mathrm{~kg} / \mathrm{m}^{2}$ & $1(11.1 \%)$ & $18(85.7 \%)$ & & \\
\hline \multicolumn{5}{|l|}{ Exercise } \\
\hline No regular & $6(66.7 \%)$ & $1(4.8 \%)$ & 14 & 0.001 \\
\hline Regular & $3(33.3 \%)$ & $20(95.2 \%)$ & & \\
\hline \multicolumn{5}{|l|}{ Diet } \\
\hline Not compliant & $7(77.8 \%)$ & $1(4.8 \%)$ & 16.3 & 0.0001 \\
\hline Compliant & $2(22.2 \%)$ & $20(95.2 \%)$ & & \\
\hline \multicolumn{5}{|l|}{ Smoking habit } \\
\hline Smoking & $6(66.7 \%)$ & $1(4.8 \%)$ & 14 & 0.001 \\
\hline Non-smoking & $3(33.3 \%)$ & $20(95.2 \%)$ & & \\
\hline
\end{tabular}


LDL-C rises too [5]. However, there were some studies which showed that sex did not affect the TC reduction. John et al [25] in his research stated that control of dyslipidemia did not vary significantly across ethnic-sex group and prevalence of dyslipidemia did not differ significantly between women and men. Cooke and Hammerash [26] also reported the same. They showed that there were no significant sex differences in potency groups to manage dyslipidemia. Another study by Syed et al [27] showed that there were no significant reductions in serum TC and LDC-C levels in both male and female patients $(p>0.05)$.

Another factor was BMI. In this study BMI gave $\mathrm{OR}=6.2$ and $p=0.0001$. This result shows that there was a significant correlation between BMI and $\mathrm{TC}$ reduction. Freeman and Junge [5] stated that high BMI or body weight increases the risk of a higher TC level. Denke [28] explained that there was a relationship between body weight changes and serum TC level among people between adults and middle age.

Exercising regularly could lower the levels of TC, LDL-C, and triglycerides in humans [29]. This study shows a significant difference between patients who exercised regularly and those who did not $(\mathrm{OR}=14 ; p=0.001)$. Kuriyan et al [30] produced same results with this study. They explained that physical activity reduces most of the artherosclerotic risk factors and regular exercise has been shown to reduce LDL-C and triglycerides.

Lifestyle modification to normalize body weight and having healthy patterns of dietary intake might give a significant result in serum TC reduction. Individualized dietary intake for reducing $\mathrm{TC}$ level in blood have shown to be modestly effective. Diets low in saturated fat and cholesterol could lower LDL-C [30]. Our study showed that diet could decrease TC level. A comparison between patients with a good diet and those without showed significant differences in $\mathrm{TC}$ reduction $(\mathrm{OR}=16.3 ; p=0.0001)$.

One other factor that influenced the reduction of TC level was smoking habits $(\mathrm{OR}=14 ; p=$ 0.001 ). A cigarette contains many toxins such as tar, nicotine and carbon monoxide. Smoking can decrease the oxygen serum level and lead to elevation in heart rate, reduction in high density lipids (HDL) and damage of endothelium [31]. Jacobson [32] stated that there was a correlation between smoking and TC level while Schultemaker [33] explained that there was a significant difference in the TC levels of patients who smoked and those who do not. Shi-Dou Lin et al [34] also found that TC level is related to smoking habits. Thus, the findings are buttressed those of the cited above, especially with regard to correlation between smoking habit and reduction in $\mathrm{TC}$ level.

No serious adverse effects were reported during the present study. Adverse events were just limited to mild gastrointestinal symptoms such as flatulence and abdominal distention after the first few doses but the symptoms subsided within a week in all subjects.

\section{CONCLUSION}

The results indicate that $1 \mathrm{~g}$ extract, when given orally three times a day, significantly reduces TC and LDL-C levels. It seems that consumption of MCC when combined with suitable control of some factors such as age, BMI, diet, exercise and smoking habit significantly reduces TC levels in patients. The results from this study justify the medicinal use of Morinda citrifolia in hypercholesterolemia and may also be of relevance in the treatment of cardiovascular diseases.

\section{ACKNOWLEDGEMENT}

The authors gratefully acknowledge the Laboratory of Biomedika, PT. Puspa Pharma, Universitas Indonesia for support for this study.

\section{REFERENCES}

1. Cipolle C. Hypercholesterolemia, Care Plan Guidelines. Peters Institute of Pharmaceutical Care; 2004; pp 118

2. Kane GC, Lipsky JJ. High cholesterol (hypercholesterolemia). Mayo Clin Proc 2000; 75: 933-942.

3. Indonesian Society of Endocrinology. Petunjuk Praktis Penatalaksanaan Dislipidemia. Cetakan Pertama. Jakarta; 2004

4. ESC/EAS Committee. ESC/EAS Guidelines for the Management of Dyslipidaemias. The Task Force for the Management Of Dyslipidaemias of The European Society of Cardiology (ESC) and The European Atherosclerosis Society (EAS). Eur Heart J 2011; 32: 1769-1818.

5. Freeman WF, Junge C. Lowering Your Cholesterol. Harvard: Harvard College; 2008

6. NCEP-ATP III (National Cholesterol Education Program Adult Treatment Panel III). The Third Report of The NCEP Expert Pannel Excecutive Summary. Detection Evaluation and Treatment of The High Blood Cholesterol in Adult. NCEP, NHL and Blood Institute 2001.; $01-3670$

Trop J Pharm Res, August 2014; 13(8): 1324 
7. Bhatnagar $D$, Soran $H$, Durrington $P N$. Hypercholesterolaemia and Its Management. BMJ 2008; 337: a993.

8. Wiart C. Medicinal Plants of The Asia-Pasific: Drugs for The Future? Singapore: World Scientific Publishing Co. Pte. Ltd; 2006.

9. Potterat O, Hamburger M. Morinda citrifolia (noni) FruitPhytochemistry, Pharmacology, Safety. Planta Med 2007; 73: 191-199.

10. Wang MY, West BJ, Jensen CJ, Nowicki D, Chen S, Palu $A K$, and Anderson G. Morinda citrifolia (Noni): $A$ Literature Review and Recent Advances in Noni Research. Acta Pharmacol Sin 2002; 23(12): 11271141.

11. Chearskul S, Kooptiwut S, Chatchawalvanit S, Onreabroi $S$, Churintrapun $M$, Saralamp $P$ and Soonthorncharennon. Morinda citrifolia Has Very Weak Estrogen Activity in Vivo. Thai J Physiol Sci 2004; 17(1): 22-29.

12. Pancasila University. Laporan Hasil Uji Toksisitas Akut Kapsul Pacekap® pada Mencit. Production of PT. Jamu Puspo Internusa; 2012.

13. Issel BF, Gotay C, Pagano I, Franke A. Quality of Life Measures in A Phase I Trial of Noni. J Clin Oncol 2005; 23: 782s.

14. Mandukhail SR, Aziz N, Anwarul-Hassan AH. Studies on Antidyslipidemic Effects of Morinda citrifolia (Noni) Fruit, Leaves and root extracts. Lipids Health Dis 2010; 9: 88.

15. Wang MY, Nowicki D, Anderson G. The Heart Protection Study: Improvement of Lipoprotein Profiles in Current Smokers Receiving Morinda citrifolia (noni) Fruit Juice. The 44th Annual Conference on Cardiovascular Disease Epidemiology and Prevention in Association with the Council on Nutrition, Phyical Activity, and Metabolism, American Heart Association. Phoenix, Arizona. J Am Heart Assoc 2004; 09: e71-e144.

16. Wang MY, Henley E, Nolting J, Cheerva A, Jensen J, Anderson G, Nowicki D, Story S. The Effects of Morinda citrifolia (noni) Fruit Juice on Serum Cholesterol and Triglycerides in Current Smokers. The 46th Annual Conference on Cardiovascular Disease Epidemiology and Prevention in Association with the Council on Nutrition, Phyical Activity, and Metabolism, American Heart Association. Phoenix, Arizona J Am Heart Assoc 2006; 113: e301-e381.

17. Wang MY, Peng L, Weidenbacher Hoper V, Deng S, Anelerson G, West BJ. Noni Juice Improves Serum Lipid Profiles and Other Risk Markers in Cigarette Smokers. Sci World J 2012; 94657. DOI: 10.1100/2012/594657.

18. WMA. WORLD MEDICAL ASSOCIATION DECLARATION OF HELSINKI - Ethical Principles for Medical Research Involving Human Subjects. World Medical Association, Seoul, Korea, 2008

19. Ramamoorthy PK, Bono A. Antioxidant Activity, Total Phenolic and Flavonoid Content of Morinda citrifolia fruit extracts from various extraction process. J Eng Sci Tech 2007; 2 (1): 70-80

20. Palu, 'A K, Brett J W, Jarakae J, Bing-Nan Z. Morinda citrifolia L. Noni has Cholesterol Lowering Potential. Folk Botanical Wisdom: Towards Global Markets. June 5-9; 2006

21. Subramanian S, Rao OSM. Biochemical Evaluation of Antihyperglycemia and Anti Oxidative Effects of Morinda citrifolia Extract Studied in Streptozotosin Induced Diabetic Rats. J Med Chem 2009; 19: 433446.

22. Devroey $D$, Swaef $N D$, Coigniez $P$, Vandervoorde J, Kartonuian J, Betz W. Correlations Between Lipid Levels and Age, Gender, glycemia, obesity, diabetes and smoking. Endocr Res 2004; 30: 83-93.

23. Raitakari OT, Juonala M, Vikari JSA. Obesity in childhood and vascular changes in adulthood: insights into the cardiovascular risk in Young Finns study. Int $J$ Obes 2005; 19: 101-104.

24. Indonesia Health Household Survey. Rancangan Survei Kesehatan Rumah Tangga Volume 1. Jakarta. Badan Penelitian \& Pengembangan Kesehatan Depkes Rl; 2004.

25. John G, Sharon LR, Jeffrey JA. Ethnic and Sex differences in the prevalence, treatment and control of dyslipidemia among hypertensive adults in the GENOA study. Arch Intern Med 2004; 164: 13131317

26. Cooke CE, Hammerash WJ. Retrospective review of sex differences in the management of dyslipidemia in coronary heart disease: an analysis of patient data from a Maryland-based health maintenance organization. Medline, PubMed: 16750470; 2005

27. Syed YHG, Saima B, Nazir A, Syed RAS. Gender differences of dyslipidemia in type 2 diabetics. $J$ Ayub Med Coll Abbottabad 2010; 22 (3).

28. Denke MA. Nutrient and Genetic Regulations of Lipoprotein Metabolism in Modern Nutrition in Health and Disease. USA: Lippincott Williams \& Wilkins; 2006.

29. Aires N, Selmer R, and Thelle D. The Validity of SelfReported Leisure Time Physical Activity, and Its Relationship to Serum Cholesterol, Blood Pressure and Body Mass Index. A Population Based Study of 332,182 Men and Women Aged 40-42 years. Eur J Epidemiol 2003; 18 (6): 479-485.

30. Kuriyan R, Kumar DR, Rajendran R, Kurpad AV. An evaluation of the hypolipidemic effect of an extract of Hibiscus Sabdariffa leaves in hyperlipidemic Indians: a double blind, placebo controlled trial. Complement Altern Med 2010; 10: 27

31. Indonesian Health Ministry. Keputusan Menteri kesehatan Republik Indonesia Nomor 854/MENKES/SK/IX/2009 Tentang Pedoman Pengendalian Penyakit Jantung dan Pembuluh Darah. Jakarta: Indonesian Health Ministry; 2009.

32. Jacobson BH, Aldana SG, Adams TB, Quirk M. The relationship between smoking, cholesterol, and HDL-

Trop J Pharm Res, August 2014; 13(8): 1325 
C levels in adult women. Women Health 1995; 23: 27-29

33. Schultemaker. Relationship between smoking habits and low-density lipoprotein-cholesterol, high-density lipoprotein cholesterol, and triglycerides in a percholesterolemic adult cohort, in relation to gender and age. Clin Exp Med 2002: 83-88.

34. Shi-Dou L, Shih-Te T, Shang-Ren H, Kwo-Chuan L, Wayne HHS. Characteristics Predicting Dyslipidemia in Drug-naïve Type 2 Diabetes Patients. J Chin Med Assoc (2006); 69 (9): 404-408. 